\title{
LOADING AND UNLOADING BREATHING DURING EXERCISE: RESPIRATORY RESPONSES AND COMPENSATORY MECHANISMS
}

\author{
M. O. Segizbaeva \\ Laboratory of Respiration Physiology, Pavlov Institute of Physiology, Russian Academy of Sciences, Saint Petersburg, Russia
}

\begin{abstract}
To characterize the ventilatory responses to resistive loading or unloading, we studied the effects of breathing $79 \%$ helium-21\% oxygen $\left(\mathrm{He}-\mathrm{O}_{2}\right), 79 \%$ argon-21\% oxygen $\left(\mathrm{Ar}-\mathrm{O}_{2}\right)$ and $79 \% \mathrm{SF}_{6}-21 \%$ oxygen $\left(\mathrm{SF}_{6}-\mathrm{O}_{2}\right)$ on the volume-time parameters, end-tidal partial pressure of $\mathrm{CO}_{2}\left(\mathrm{P}_{\mathrm{ET}} \mathrm{CO}_{2}\right)$, mouth pressure $\left(\mathrm{P}_{\mathrm{Im}}\right)$, work of breathing $\left(\mathrm{W}_{\mathrm{I}}\right)$, central inspiratory activity $\left(\mathrm{dP} / \mathrm{dt}_{\mathrm{I}}\right)$, and electromyographic activity of parasternal inspiratory muscles (EMGps) in 10 normal subjects at rest and during short-time steady-state exercise. There were no significant changes in tidal volume $\left(V_{T}\right)$, breathing frequency $(f)$, inspiratory $\left(T_{I}\right)$ and expiratory $\left(\mathrm{T}_{\mathrm{E}}\right)$ durations, minute ventilation $\left(\mathrm{V}_{\mathrm{E}}\right)$, and $\mathrm{P}_{\mathrm{ET}} \mathrm{CO}_{2}$ when air was replaced by $\mathrm{He}-\mathrm{O}_{2}$ or $\mathrm{SF}_{6}-\mathrm{O}_{2}$ at rest. $\mathrm{V}_{\mathrm{E}}$ and $\mathrm{P}_{\mathrm{ET}} \mathrm{CO}_{2}$ were not significantly different after replacement of air by $\mathrm{He}-\mathrm{O}_{2}$ or $\mathrm{SF}_{6}-\mathrm{O}_{2}$ during exercise. However, inhalation of $\mathrm{He}-\mathrm{O}_{2}$ decreased in $\mathrm{V}_{\mathrm{T}}$ and increased in $\mathrm{f}$, whereas inhalation of $\mathrm{SF}_{6}-\mathrm{O}_{2}$ led to the opposite effects compared with air during exercise. Both at rest and exercise, $\mathrm{P}_{\mathrm{Im}}, \mathrm{W}_{\mathrm{I}}, \mathrm{dP} / \mathrm{dt}_{\mathrm{I}}$ and EMGps were significantly less during $\mathrm{He}-\mathrm{O}_{2}$ breathing and higher during $\mathrm{SF}_{6}-\mathrm{O}_{2}$ breathing $(\mathrm{P}<0.01)$ from the first respiratory cycle after room air was replaced by $\mathrm{He}-\mathrm{O}_{2}$ or $\mathrm{SF}_{6}-\mathrm{O}_{2}$. Ar- $\mathrm{O}_{2}$ breathing did not affect the time-volume parameters both at rest and during exercise compared with air. The increase in $\mathrm{P}_{\mathrm{Im}}, \mathrm{W}_{\mathrm{I}}$, and $\mathrm{dP} / \mathrm{dt}_{\mathrm{I}}$ was observed at $\mathrm{Ar}-\mathrm{O}_{2}$ inhalation during exercise relatively to air conditions $(\mathrm{P}<0.05)$. We conclude that internal resistive loaded $\left(\mathrm{SF}_{6}-\mathrm{O}_{2}\right)$ or unloaded $\left(\mathrm{He}-\mathrm{O}_{2}\right)$ breathing changes the neuromuscular output required to maintain constant ventilation. The mechanisms of load or unload compensation seem to be mediated by afferent information from lung and respiratory muscle receptors as well as by segmentary reflexes and properties of muscle fibers.
\end{abstract}

Key words: control of breathing, loaded and unloaded breathing, exercise, respiratory muscle function, $\mathrm{He}-$ $\mathrm{O}_{2}, \mathrm{Ar}-\mathrm{O}_{2}, \mathrm{SF}_{6}-\mathrm{O}_{2}$

\section{INTRODUCTION}

Studies of ventilatory responses to altered mechanical loads in conscious humans have provided new insights into adaptive capabilities of the respiratory system. Compensatory responses to resistive loads or unloads have been variously considered to be mediated by the neural, humoral mechanisms, or a combination of both. However, despite the numerous clinical and experimental studies the specific mechanisms participating in compensatory responses to changing resistive load, the order of their involvement and the degree of contribution are not fully understood. The use of gas mixtures with different density is one way to simulate loaded or unloaded breathing. This technique allows for changes in the resistive loading over the whole tracheobronchial tree without a mechanical effect on the bronchial tone. Gas mixtures of different densities have been widely accepted in different areas of human occupational activity, functional diagnostics, and clinic practice $[1,2]$.

Studies have produced mixed results regarding the effects of loaded and unloaded breathing on respiratory responses and exercise capacity. It is known that an increase or decrease in gas mixtures density does not significantly affect the respiratory system at rest [3, 4], but during exercise this factor may be essential, since the dependence of the non-elastic resistance from density gas mixtures increases with the growth of respiratory flow rates in accordance with Rorer's equation. Resistive load during exercise evokes a compensatory increase in respiratory drive which, for mild loads imposed at low work rates, can preserve ventilation at the control unloaded level [5]. During high levels of exercise and/or heavy resistive load, compensation appears inadequate as evidenced by a relative hypopnea [5]. Conversely, density-dependent unloading of the respiratory system at high work rates has been shown to cause hyperventilation $[3,6]$. Previous studies of $\mathrm{He}-\mathrm{O}_{2}$ breathing have demonstrated rapid compensatory responses to decreased airway resistance [3, 7]. Inspiratory occlusion pressure and neural inspiratory drive are reduced during $\mathrm{He}-\mathrm{O}_{2}$ breathing at rest [4] and during exercise [7], thus lessening the disturbance in ventilation caused by resistance unloading. Mechanisms of such compensation and their relative contributions have been difficult to assess and remain unresolved. However, both intrinsic properties of respiratory muscles and mechanoreceptor-mediated neural reflexes are thought to contribute to responses to altered resistance loads $[3,4]$. Therefore, to characterize the response of respiration and to evaluate the possible compensatory mechanisms to resistive loading and unloading, we studied the effects of normoxic gas mixtures with different density on the ventilatory con- 
trol in normal subjects during short-time steady-state exercise.

\section{MATERIAL AND Methods}

\section{STUDY SUBJECTS}

The study was approved by a local Ethics Committee and conducted in accordance with the ethical standards of the Helsinki Declaration for Experimentation on Human Subjects. All subjects were familiarized with the experimental procedures and gave informed consent. Ten healthy, nonsmoking male subjects participated in the study. Their mean age was $29.8 \pm 2.4$ yr, height $177.8 \pm 3.1 \mathrm{~cm}$, weight $74.6 \pm 3.8 \mathrm{~kg}$, and vital capacity (VC) $4.7 \pm 0.71$. All of them had no history of cardiorespiratory diseases and had ventilatory functions within normal limits.

\section{EXPERIMENTAL PROTOCOL}

The study was of a randomized crossover design, which required ten separate visits to the laboratory. Conditions between experiments were standardized as far as possible: the subject was requested to refrain from taking stimulants or exercising for $24 \mathrm{~h}$ before a test, and from eating within $1 \mathrm{~h}$ prior to the experiment. On the enrollment day, all subjects had spirometry and underwent an incremental (30 W/every $3 \mathrm{~min})$ cycle ergometer (Jaeger) exercise to exhaustion to measure maximal work rate. During another visit, a constant-load exercise at $50 \%$ of the maximum work rate with a pedaling frequency of $60 \mathrm{rpm}$ was performed to examine the effects of high and low density gas mixtures on the respiratory responses. The following gas mixtures were studied: helium-oxygen mixture - heliox $\left(21 \% \mathrm{O}_{2}, 79 \% \mathrm{He}\right)$, argon-oxygen mixture $\left(21 \% \mathrm{O}_{2}, 79 \% \mathrm{Ar}_{2}\right)$, and sulfur hexafluoride-oxygen mixture $\left(21 \% \quad \mathrm{O}_{2}, 79 \% \quad \mathrm{SF}_{6}\right)$. Subjects breathed through a two-way low-resistance valve in the sitting position. The inspiratory part of the valve was connected to a 60-liter Douglas bag in which the humidified mixtures, coming from a gas tank, were collected. A 7 to 10 -min equilibration period preceded data collection during each breathing trial to allow the subjects to adjust to the apparatus and achieve a regular relaxed breathing pattern. At rest and during exercise an abrupt, but surreptitious, substitution of inhaled gas mixtures was implemented (air (5 min) $\rightarrow \mathrm{He}^{-\mathrm{O}_{2}}$ (3 $\mathrm{min}) \rightarrow$ air $(3 \mathrm{~min})$, air $\rightarrow \mathrm{Ar}-\mathrm{O}_{2} \rightarrow$ air, air $\rightarrow \mathrm{SF}_{6}-\mathrm{O}_{2} \rightarrow$ air $)$. Subjects were not aware with which gas mixture they breathed. On average, each subject completed 9 tests in a randomized sequence; that is three tests of each type. The breath-by-breath responses in respiratory parameters were derived for each test. The mean values of three tests for the same experimental conditions were utilized for statistical purposes, after a good repeatability of the measured variables was confirmed.

\section{Ventilation And Alveolar $\mathrm{CO}_{2}$}

Inspiratory flow $\left(\mathrm{V}_{\mathrm{I}}\right)$ was measured with a pneumotachograph (Fleish No. 3), connected to the inspiratory port of the low-resistance valve (Hans Rudolph, 2700). The inspiratory flow signal was electronically integrated to yield tidal volume $\left(\mathrm{V}_{\mathrm{T}}\right)$ and was displayed on the multichannel recorder. Inspiratory and expiratory time $\left(\mathrm{T}_{\mathrm{I}}, \mathrm{T}_{\mathrm{E}}\right)$, total breath cycle $\left(\mathrm{T}_{\mathrm{T}}\right)$, and breathing frequency $(\mathrm{f})$ were measured from this tracing. Minute ventilation $\left(V_{E}\right)$ was calculated as a product of $\mathrm{V}_{\mathrm{T}}$ and $\mathrm{f}$. Volume calibration was performed for each inspiratory gas mixture at several flow rates using a 1 $\mathrm{L}$ syringe. End-tidal partial pressure of $\mathrm{CO}_{2}\left(\mathrm{P}_{\mathrm{ET}} \mathrm{CO}_{2}\right)$ was sampled continuously at the expiratory port of the valve and the peak end-tidal values recorded by an MX 6203 mass spectrometer (Russia). Calibration of the system was performed at each gas mixture immediately before and after each test.

\section{Mouth Pressure and Neuromuscular Output}

A mouth pressure $\left(\mathrm{P}_{\mathrm{Im}}\right)$ was measured using a pressure tap at the mouthpiece connected to a differential pressure transducer (PDP 1000 MD, Russia). Neuromuscular control of breathing was assessed by analysis of electromyography of parasternal inspiratory muscles and the maximum rate of inspiratory mouth pressure change. The mouth pressure signal was electronically differentiated to yield the instantaneous rate of pressure change $\left(\mathrm{dP} / \mathrm{dt}_{\mathrm{I}}\right)$. Measurements of $\mathrm{dP} / \mathrm{dt}_{\mathrm{I}}$ represent a useful noninvasive index of the output of the respiratory center, which depends only on the neuronal discharge and the effectiveness of the inspiratory muscles contraction [8]. The inspiratory work of breathing was calculated as the product of $\mathrm{P}_{\mathrm{Im}}$ and tidal volume. Signals from the pneumathohograph and pressure transducer were converted to a digital signal using a data system (Biograph, Russia). All data were stored on a computer for off-line analysis.

\section{Muscle Activity Measurements}

Electromyographic activity (EMG) was recorded from the parasternal intercostals muscles using surface electrodes. Electrodes were placed on the second and third intercostals spaces just right of the sternal line. EMG signals were amplified and electronically integrated on-line on a computer IBM PC. The peak amplitude of integrated EMG of parasternal muscles (Eps) was assessed in this study.

\section{DATA ANALYSis}

All data are reported in absolute values as means \pm SE. An analysis of variance was performed on all data to determine the effect of loaded and unloaded breathing compared with normal breathing during rest and exercise. Student's $t$-test was used to detect differences between mean. $\mathrm{P}<0.05$ has been taken as statistically significant.

\section{RESULTS}

\section{EFFECTS OF He-O 2 ON RESPIRATION}

The mean data for each variable during air and $\mathrm{He}-\mathrm{O}_{2}$ breathing at rest and exercise are shown in Tables 1 and 2 , respectively. In the steady-state at rest, abruptly substituting the helium-oxygen mixture for room air did not influence volume-time parameters and $\mathrm{P}_{\mathrm{ET}} \mathrm{CO}_{2}$, either during the first few breaths or over the subse- 

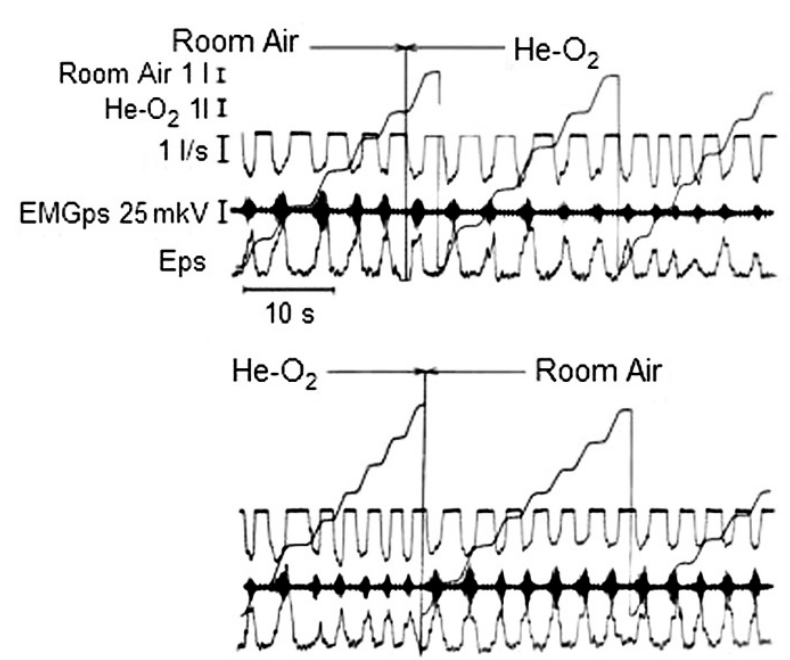

Fig. 1. Inspiratory flow rate, tidal volume, EMG raw and integrated (Eps) activity of parasternal inspiratory muscles in response to abrupt substitution of helium-oxygen mixture $\left(\mathrm{He}-\mathrm{O}_{2}\right)$ for room air (and vice versa) in the steady-state exercise in subject $\mathrm{N} 3$. quent 3 min of inhaling the low-density mixture. Likewise, the reverse substitution $\left(\mathrm{He}-\mathrm{O}_{2} \rightarrow\right.$ air $)$ was without an effect. Helium-based mixture significantly increased peak inspiratory flow rates. The heliox breathing, however, had a significantly greater effect during exercise compared with resting conditions. An individual example of ventilatory effects of air-to-heliox and backward switches during exercise is shown in Fig. 1. The figure depicts typical changes in parasternal EMG activity during exercise after the replacement of room air by $\mathrm{He}_{-} \mathrm{O}_{2}$. Peak amplitude of integrated EMG (Eps) decreased when air was switched to He- $\mathrm{O}_{2}(\sim 40 \%)$ and generally increased when vice versa.

During exercise, inhalation of the helium-oxygen mixture evoked a small, but significant, reduction in $\mathrm{V}_{\mathrm{T}}$ and an increase in $\mathrm{f}(\mathrm{P}<0.05)$. At the same time, no significant differences between the gases were found in $\mathrm{V}_{\mathrm{E}}$ and $\mathrm{P}_{\mathrm{ET}} \mathrm{CO}_{2}$ during exercise (Table 2). Both at rest and during exercise, helium breathing induced an immediate significant decrease in $\mathrm{P}_{\operatorname{Im}}(34$ and $40 \%$, respectively) and $\mathrm{W}_{\mathrm{I}}$, (30 and $39 \%$, respectively), which were discernible during the first breaths (Figs. 2 and 3). He-
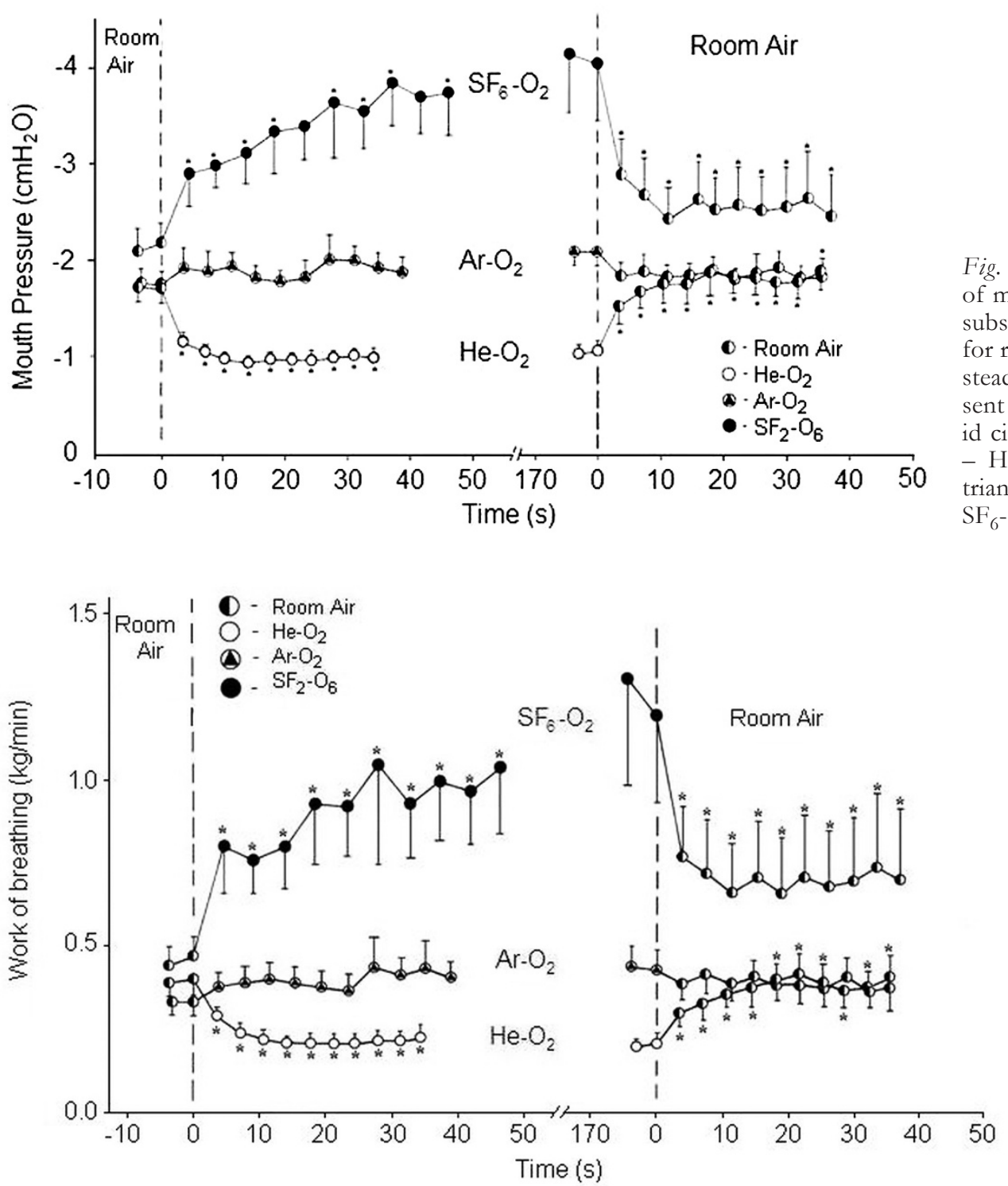

Fig. 2. Breath-by-breath responses of mouth pressure $\left(\mathrm{P}_{\mathrm{Im}}\right)$ to abrupt substitution of the gas mixtures for room air (and vice versa) during steady-state exercise. Values represent means $\pm S D, 1 / 2$ open $+1 / 2$ solid circles - Room air; open circles - $\mathrm{He}-\mathrm{O}_{2}$; open circles with solid triangles - Ar- $\mathrm{O}_{2}$; solid circles $\mathrm{SF}_{6}-\mathrm{O}_{2}$.
Fig. 3. Breath-by-breath re-
sponses of work of breath-
ing $\left(\mathrm{W}_{\mathrm{I}}\right)$ to abrupt substitu-
tion of the gas mixtures for
room air (and vice versa)
during steady-state exercise.
Values represent means
$\pm \mathrm{SD}, 1 / 2$ open $+1 / 2$ solid cir-
cles $-\mathrm{Room}$ air; open cir-
cles $-\mathrm{He}-\mathrm{O}_{2} ;$ open circles
with solid triangles - Ar- $\mathrm{O}_{2}$;
solid circles $-\mathrm{SF}_{6}-\mathrm{O}_{2}$. 


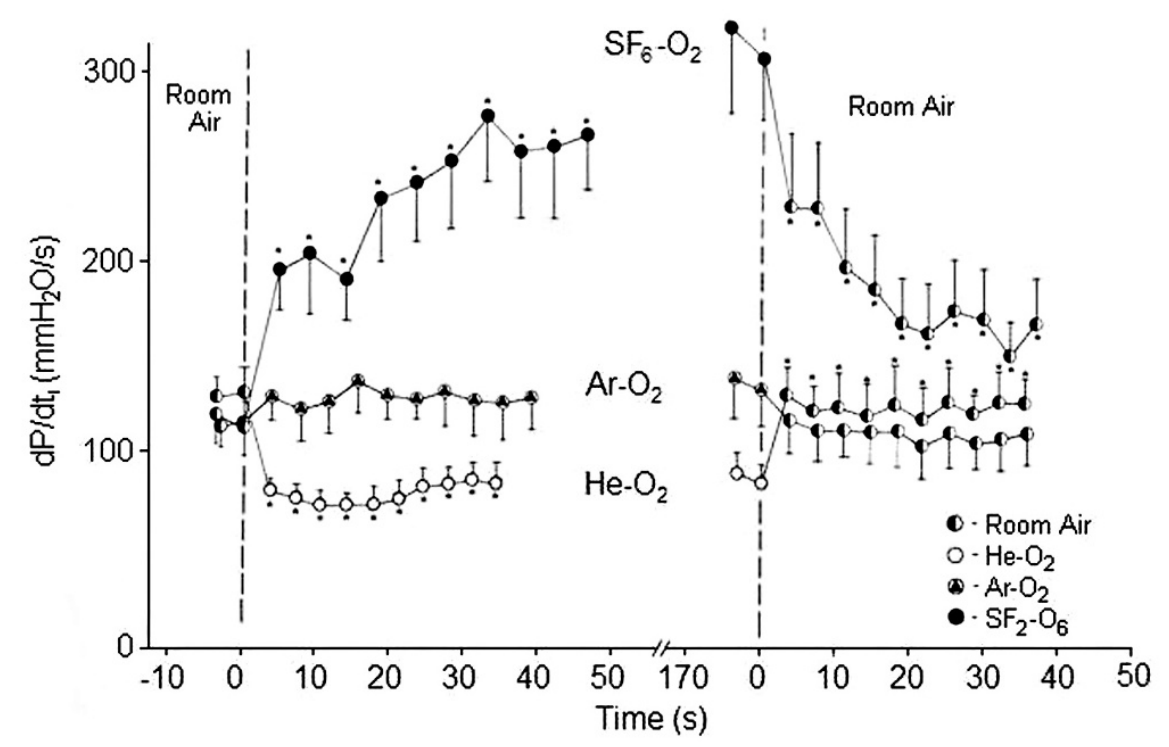

Fig. 4. Breath-by-breath responses of central inspiratory activity $\left(\mathrm{dP} / \mathrm{dt}_{\mathrm{I}}\right)$ to abrupt substitution of the gas mixtures for room air (and vice versa) during steady-state exercise. Values represent means $\pm \mathrm{SD}, 1 / 2$ open $+1 / 2$ solid circles - Room air; open circles - He$\mathrm{O}_{2}$; open circles with solid triangles Ar- $\mathrm{O}_{2}$; solid circles $-\mathrm{SF}_{6}-\mathrm{O}_{2}$.

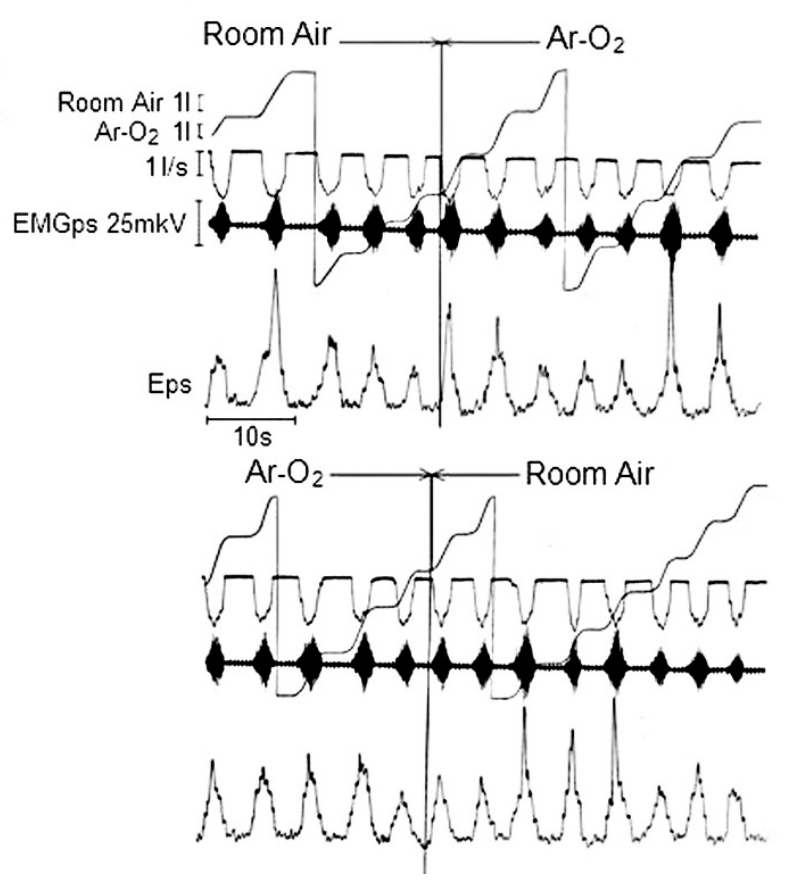

Fig. 5. Inspiratory flow rate, tidal volume, EMG raw and integrated (Eps) activity of parasternal inspiratory muscles in response to abrupt substitution of argon-oxygen mixture $\left(\right.$ Ar- $\left.\mathrm{O}_{2}\right)$ for room air (and vice versa) during steady-state exercise in subject $\mathrm{N} 3$.

$\mathrm{O}_{2}$ breathing resulted in a significant reduction in $\mathrm{dP} / \mathrm{dt}_{\mathrm{I}}$ (Fig. 4). The mean reduction in $\mathrm{dP} / \mathrm{dt}_{\mathrm{I}}$ was $28 \%$ at rest and $29 \%$ during exercise $(\mathrm{P}<0.01)$. Conversely, the substitution of room air for the heliumoxygen mixture elicited the reverse pattern of responses (Figs. 2, 3, and 4).

\section{EFFECTS OF AR-O 2 ON RESPIRATION}

During quiet breathing at rest, ventilatory parameters were unaffected by argon-oxygen mixture (Table 1). During exercise, volume-time values also were similar

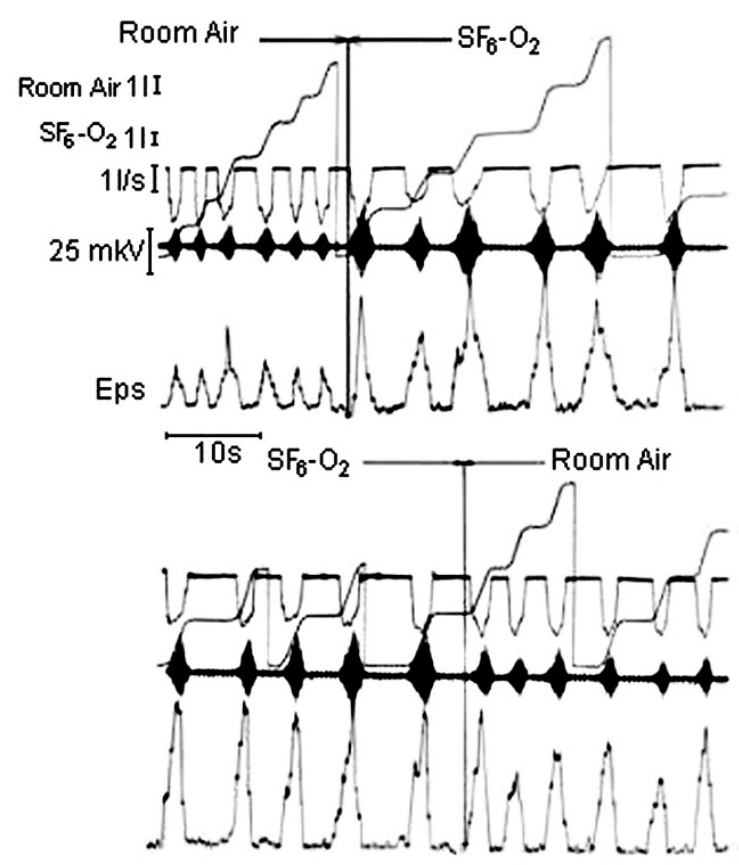

Fig. 6. Inspiratory flow rate, tidal volume, EMG raw and integrated (Eps) activity of parasternal inspiratory muscles in response to abrupt substitution of sulfur hexafluoride-oxygen mixture $\left(\mathrm{SF}_{6}-\mathrm{O}_{2}\right)$ for room air (and vice versa) during the steady-state exercise in subject N3.

to those with air while breathing $\mathrm{Ar}-\mathrm{O}_{2}$ (Table 2). No difference in the peak inspiratory flow was observed between room air and $\mathrm{Ar}-\mathrm{O}_{2}$. All subjects demonstrated the same $\mathrm{P}_{\mathrm{ET}} \mathrm{CO}_{2}$ in air and $\mathrm{Ar}-\mathrm{O}_{2}$ during both rest and exercise. Similar resting $\mathrm{P}_{\mathrm{Im}}, \mathrm{W}_{\mathrm{I}}$, and $\mathrm{dP} / \mathrm{dt}_{\mathrm{I}}$ were observed with argon-oxygen mixture compared with air. Small increases in $\mathrm{P}_{\mathrm{Im}}, \mathrm{W}_{\mathrm{I}}$, and $\mathrm{dP} / \mathrm{dt}_{\mathrm{I}}$ were observed on switch to $\mathrm{Ar}^{-\mathrm{O}_{2}}$ during exercise (10, 15 , and 13\%, respectively; $\mathrm{P}<0.05$ ) (Figs. 2, 3, and 4). Eps remained constant during air and Ar- $\mathrm{O}_{2}$ breathing during both resting and exercising conditions (Fig. 5). 
Table 1. Respiratory variables during rest in room air, $\mathrm{He}-\mathrm{O}_{2}, \mathrm{Ar}-\mathrm{O}_{2}$, and $\mathrm{SF}_{6}-\mathrm{O}_{2}$ breathing.

\begin{tabular}{lcccccc}
\hline Parameters & Room Air & $\mathrm{He}_{2}$ & Room air & Ar-O & Room air & $\mathrm{SF}_{6}-\mathrm{O}_{2}$ \\
\hline $\mathrm{V}_{\mathrm{E}}, \mathrm{l} / \mathrm{min}$ & $8.89 \pm 0.51$ & $9.28 \pm 0.56$ & $9.06 \pm 0.50$ & $9.07 \pm 0.54$ & $9.01 \pm 0.69$ & $8.95 \pm 0.55$ \\
$\mathrm{~V}_{\mathrm{T}}, \mathrm{l}$ & $0.86 \pm 0.18$ & $0.92 \pm 0.19$ & $0.79 \pm 0.11$ & $0.85 \pm 0.14$ & $0.86 \pm 0.17$ & $0.94 \pm 0.15^{*}$ \\
$\mathrm{~T}_{\mathrm{I}}, \mathrm{s}$ & $2.46 \pm 0.62$ & $2.42 \pm 0.56$ & $2.11 \pm 0.38$ & $2.36 \pm 0.48$ & $2.51 \pm 0.58$ & $2.94 \pm 0.70$ \\
$\mathrm{~T}_{\mathrm{E}}, \mathrm{s}$ & $3.43 \pm 0.58$ & $3.52 \pm 0.69$ & $3.38 \pm 0.44$ & $3.44 \pm 0.51$ & $3.53 \pm 0.55$ & $3.59 \pm 0.51$ \\
$\mathrm{~T}_{\mathrm{T}}, \mathrm{s}$ & $5.59 \pm 0.78$ & $5.95 \pm 1.15$ & $5.49 \pm 0.78$ & $5.80 \pm 0.99$ & $6.04 \pm 1.14$ & $6.53 \pm 1.15^{*}$ \\
$\mathrm{f}, \mathrm{cycle} / \mathrm{min}$ & $12.7 \pm 1.4$ & $12.5 \pm 1.4$ & $13.2 \pm 1.7$ & $12.7 \pm 1.5$ & $12.3 \pm 1.5$ & $11.3 \pm 1.7 *$ \\
$\mathrm{P}_{\mathrm{A}} \mathrm{CO}_{2}, \mathrm{mmHg}$ & $33.9 \pm 1.1$ & $33.5 \pm 1.2$ & $33.9 \pm 1.1$ & $34.9 \pm 1.2$ & $33.3 \pm 0.7$ & $33.4 \pm 1.0$ \\
$\mathrm{~V}_{\mathrm{Imax}}, \mathrm{l} / \mathrm{s}$ & $0.42 \pm 0.02$ & $0.57 \pm 0.04^{*}$ & $0.48 \pm 0.04$ & $0.50 \pm 0.03$ & $0.44 \pm 0.02$ & $0.34 \pm 0.02^{*}$ \\
$\mathrm{P}_{\mathrm{Im}}, \mathrm{cmH} \mathrm{H}_{2} \mathrm{O}$ & $0.70 \pm 0.05$ & $0.46 \pm 0.07 *$ & $0.76 \pm 0.06$ & $0.80 \pm 0.12$ & $0.74 \pm 0.05$ & $1.05 \pm 0.03^{* *}$ \\
$\mathrm{~W}_{\mathrm{I}}, \mathrm{kgm} / \mathrm{min}$ & $0.06 \pm 0.01$ & $0.04 \pm 0.07$ & $0.07 \pm 0.01$ & $0.07 \pm 0.01$ & $0.07 \pm 0.01$ & $0.01 \pm 0.01 * *$ \\
$\mathrm{dP} / \mathrm{dt}, \mathrm{mmH} \mathrm{I}_{2} \mathrm{O} / \mathrm{s}$ & $32.40 \pm 3.17$ & $23.35 \pm 2.71 *$ & $31.30 \pm 3.69$ & $37.50 \pm 4.64$ & $32.70 \pm 3.38$ & $57.80 \pm 8.19^{* *}$ \\
\hline
\end{tabular}

Data are means $\pm S E$. $V_{E}$, minute ventilation; $V_{T}$, tidal volume; $T_{I}$, inspiratory time; $T_{E}$, expiratory time; $T_{T}$, total breath duration; $\mathrm{f}$, breath frequency; $\mathrm{P}_{\mathrm{A}} \mathrm{CO}_{2}$, end-tidal partial pressure; $\mathrm{V}_{\text {Imax }}$, inspiratory flow rate; $\mathrm{P}_{\text {Im }}$, inspiratory mouth pressure; $\mathrm{W}_{\mathrm{I}}$, inspiratory work of breathing; $\mathrm{dP} / \mathrm{dt}_{\mathrm{I}}$, maximum rate of inspiratory mouth pressure change. $* \mathrm{P}<0.05$, $* * \mathrm{P}<0.01$ - significant differences between air and $\mathrm{He}-\mathrm{O}_{2}$ and $\mathrm{SF}_{6}-\mathrm{O}_{2}$ breathing. The differences between air and $\mathrm{Ar}-\mathrm{O}_{2}$ breathing were insignificant.

Table 2. Respiratory variables during steady-state moderate exercise in room air, $\mathrm{He}-\mathrm{O}_{2}, \mathrm{Ar}_{-} \mathrm{O}_{2}$, and $\mathrm{SF}_{6}-\mathrm{O}_{2}$ breathing.

\begin{tabular}{lcccccc}
\hline Parameters & Room Air & He-O & Room air & Ar-O & Room air & $\mathrm{SF}_{6}-\mathrm{O}_{2}$ \\
\hline $\mathrm{V}_{\mathrm{E}}, \mathrm{l} / \mathrm{min}$ & $33.12 \pm 2.26$ & $34.52 \pm 2.68$ & $31.21 \pm 1.61$ & $32.36 \pm 1.81$ & $31.97 \pm 2.45$ & $33.55 \pm 2.24$ \\
$\mathrm{~V}_{\mathrm{T}}, \mathrm{l}$ & $2.03 \pm 0.11$ & $1.90 \pm 0.12^{*}$ & $1.91 \pm 0.16$ & $2.08 \pm 0.20$ & $2.00 \pm 0.20$ & $2.58 \pm 0.28^{* *}$ \\
$\mathrm{~T}_{\mathrm{I}}, \mathrm{s}$ & $1.83 \pm 0.19$ & $1.61 \pm 0.18$ & $1.78 \pm 0.18$ & $1.86 \pm 0.21$ & $1.82 \pm 0.22$ & $2.16 \pm 0.20^{*}$ \\
$\mathrm{~T}_{\mathrm{E}}, \mathrm{s}$ & $1.94 \pm 0.22$ & $1.80 \pm 0.16$ & $1.90 \pm 0.15$ & $2.02 \pm 0.21$ & $2.04 \pm 0.24$ & $2.39 \pm 0.25^{*}$ \\
$\mathrm{~T}_{\mathrm{T}}, \mathrm{s}$ & $3.77 \pm 0.39$ & $3.40 \pm 0.32^{*}$ & $3.68 \pm 0.32$ & $3.89 \pm 0.40$ & $3.86 \pm 0.45$ & $4.55 \pm 0.43^{*}$ \\
$\mathrm{f}, \mathrm{cycle} / \mathrm{min}$ & $17.2 \pm 1.1$ & $19.1 \pm 1.2^{*}$ & $17.3 \pm 1.5$ & $16.9 \pm 1.7$ & $17.1 \pm 1.5$ & $14.4 \pm 1.5^{*}$ \\
$\mathrm{P}_{\mathrm{A}} \mathrm{CO}_{2}, \mathrm{mmHg}$ & $44.8 \pm 1.1$ & $44.7 \pm 1.0$ & $43.9 \pm 0.7$ & $44.1 \pm 0.7$ & $45.7 \pm 0.7$ & $46.4 \pm 1.1$ \\
$\mathrm{~V}_{\mathrm{Imax}}, \mathrm{l} / \mathrm{s}$ & $1.56 \pm 0.10$ & $1.88 \pm 0.13^{*}$ & $1.59 \pm 0.09$ & $1.82 \pm 0.09$ & $1.52 \pm 0.10$ & $1.46 \pm 0.12^{*}$ \\
$\mathrm{P}_{\mathrm{Im}}, \mathrm{cmH} 2 \mathrm{O}$ & $1.74 \pm 0.16$ & $1.04 \pm 0.07^{* *}$ & $1.86 \pm 0.14$ & $2.04 \pm 0.16 *$ & $1.87 \pm 0.20$ & $3.84 \pm 0.42^{* *}$ \\
$\mathrm{~W}_{\mathrm{I}}, \mathrm{kgm} / \mathrm{min}$ & $0.60 \pm 0.09$ & $0.37 \pm 0.48^{* *}$ & $0.59 \pm 0.07$ & $0.68 \pm 0.09^{*}$ & $0.62 \pm 0.01$ & $1.34 \pm 0.18^{* *}$ \\
$\mathrm{dP}_{\mathrm{P}} \mathrm{dt}, \mathrm{mmH} \mathrm{I}_{\mathrm{I}} \mathrm{O} / \mathrm{s}$ & $129.1 \pm 12.9$ & $91.4 \pm 8.5^{* *}$ & $122.3 \pm 13.5$ & $138.2 \pm 15.9 *$ & $117.8 \pm 13.2$ & $289.3 \pm 33.7 * *$ \\
\hline
\end{tabular}

Data are means $\pm S E$. $V_{E}$, minute ventilation; $V_{T}$, tidal volume; $T_{I}$, inspiratory time; $T_{E}$, expiratory time; $T_{T}$, total breath duration; $f$, breath frequency; $\mathrm{P}_{\mathrm{A}} \mathrm{CO}_{2}$, end-tidal partial pressure; $\mathrm{V}_{\text {Imax }}$, inspiratory flow rate; $\mathrm{P}_{\text {Im }}$, inspiratory mouth pressure; $\mathrm{W}_{\mathrm{I}}$, inspiratory work of breathing; $\mathrm{dP} / \mathrm{dt}_{\mathrm{I}}$, maximum rate of inspiratory mouth pressure change. $* \mathrm{P}<0.05, * * \mathrm{P}<0.01$ - significant differences between air and $\mathrm{He}-\mathrm{O}_{2}$ and $\mathrm{SF}_{6}-\mathrm{O}_{2}$ breathing.

\section{EFFECTS OF $\mathrm{SF}_{6}-\mathrm{O}_{2}$ ON RESPIRATION}

There were no differences in $\mathrm{VE}$ and $\mathrm{P}_{\mathrm{ET}} \mathrm{CO}_{2}$ between room air and $\mathrm{SF}_{6}-\mathrm{O}_{2}$ in resting conditions $(\mathrm{P}>0.05)$. Tidal volume tended to increase with $\mathrm{SF}_{6}-\mathrm{O}_{2}$ compared with air. A longer $\mathrm{T}_{\mathrm{I}}$ and $\mathrm{T}_{\mathrm{T}}(\mathrm{P}<0.05)$, but no $\mathrm{T}_{\mathrm{E}}$ resulted in a reduction in breathing frequency during $\mathrm{SF}_{6}-\mathrm{O}_{2}$ inhalation. Compared with air, inspiratory flow rates were decreased with $\mathrm{SF}_{6}-\mathrm{O}_{2}$ (Table 1). During exercise, $\mathrm{VE}$ was similar to that on air with $\mathrm{SF}_{6}-\mathrm{O}_{2}$. Tidal volume remained increased $(\mathrm{P}<0.01)$, whereas breathing frequency was reduced $(\mathrm{P}<0.05)$ due to a rise in inspiratory and total duration (Table 2). $\mathrm{P}_{\mathrm{ET}} \mathrm{CO}_{2}$ tended to increase during loaded breathing in exercising men.
At rest, $\mathrm{SF}_{6}-\mathrm{O}_{2}$ increased mouth pressure (42\%), work of breathing (45\%), and $\mathrm{dP} / \mathrm{dt}_{\mathrm{I}}(77 \%)$ compared with air. High-density breathing led to significantly greater effects in these parameters during exercise than rest. The mean increase in $\mathrm{P}_{\operatorname{Im}}$ was $105 \%$ and that in $\mathrm{W}_{\mathrm{I}}$ was $115 \%(\mathrm{P}<0.01) . \mathrm{dP} / \mathrm{dtI}$ also was significantly higher when switched to $\mathrm{SF}_{6}-\mathrm{O}_{2}(146 \%)$. Peak amplitude of integrated EMGps increased more than twice during exercise in $\mathrm{SF}_{6}-\mathrm{O}_{2}$ compared with air, as shown in an individual example presented in Fig. 6. The reverse pattern of responses was observed after high-density mixture was replaced by room air. Breath-by-breath changes in these parameters between gases are shown in Figs. 2, 3, and 4. All changes were discernible in the first breath 
after substitution the $\mathrm{SF}_{6}-\mathrm{O}_{2}$ for room air and vice versa.

\section{Discussion}

In the present study, we have examined the ventilatory responses to resistive loading by $\mathrm{Ar}-\mathrm{O}_{2}$ or $\mathrm{SF}_{6}-\mathrm{O}_{2}$ and unloading by $\mathrm{He}-\mathrm{O}_{2}$ in normal subjects. Absolute levels of $\mathrm{V}_{\mathrm{E}}$ and $\mathrm{P}_{\mathrm{ET}} \mathrm{CO}_{2}$ did not significantly change between normal (room air) and loaded or unloaded breathing at both rest and short-time steady-state exercise. Although no significant changes were detected in variety of ventilatory measurements, we demonstrated a decrease in $\mathrm{dP} / \mathrm{dt}_{\mathrm{I}}, \mathrm{P}_{\mathrm{Im}}$, and $\mathrm{W}_{\mathrm{I}}$ during $\mathrm{He}-\mathrm{O}_{2}$ compared with air breathing. These results indicate that a lower neuromuscular output is required to achieve the same $\mathrm{V}_{\mathrm{E}}$ and $\mathrm{P}_{\mathrm{ET}} \mathrm{CO}_{2}$ during $\mathrm{He}-\mathrm{O}_{2}$ compared with air. Inhalation $\mathrm{Ar}-\mathrm{O}_{2}$ did not significantly affect the respiratory responses, because the density of this gas mixture is not much more than that of air. We showed that increases in $\mathrm{dP} / \mathrm{dt}_{\mathrm{I}}, \mathrm{P}_{\mathrm{Im}}$, and $\mathrm{W}_{\mathrm{I}}$ provided the stability of $\mathrm{V}_{\mathrm{E}}$ and $\mathrm{P}_{\mathrm{ET}} \mathrm{CO}_{2}$ during high-density $\mathrm{SF}_{6}-\mathrm{O}_{2}$ breathing. The loaded breathing was accompanied by an increase in inspiratory muscle activity sufficient to maintain a constant level of $\mathrm{V}_{\mathrm{E}}$. The effect of each gas mixture on the resistive work of breathing was related to the physical properties of both helium and $\mathrm{SF}_{6}$. The lower density of helium reduces the pressure needed to overcome airway resistance at higher flow rates by maintaining laminar flow, whereas the higher density $\mathrm{SF}_{6}-\mathrm{O}_{2}$ increases airway resistance and reduces respiratory flow. Our results reflect the ability of compensatory mechanisms to maintain constant ventilation and $\mathrm{P}_{\mathrm{ET}} \mathrm{CO}_{2}$ in the face of changing loads (within the gas density limits of $0.43\left(\mathrm{He}-\mathrm{O}_{2}\right)-6.5$ $\left.\left(\mathrm{SF}_{6}-\mathrm{O}_{2}\right) \mathrm{g} / \mathrm{l}\right)$ at rest and during short-time moderate exercise.

While the mechanisms involved in these responses are not fully understood, intrinsic properties of respiratory muscles, neural reflexes, and chemoreflexes are thought to contribute to load compensation [9]. We were interested in characterizing chemo- and mechanoreflex contributions during resistive loaded and unloaded breathing. Changes in the level of chemical stimulation have major effects on neuromuscular output. This, however, is an unlikely explanation of our results, since $\mathrm{P}_{\mathrm{ET}} \mathrm{CO}_{2}$ was similar with air and He$\mathrm{O}_{2}, \mathrm{Ar}-\mathrm{O}_{2}$, or $\mathrm{SF}_{6}-\mathrm{O}_{2}$. With our experimental design, we were able to measure variables immediately after replacement of room air by $\mathrm{He}-\mathrm{O}_{2}, \mathrm{Ar}-\mathrm{O}_{2}$, or $\mathrm{SF}_{6}-\mathrm{O}_{2}$; therefore, we could determine the factors responsible for the initial compensatory response to loading and unloading. The results show that a change in respiratory effort occurred during the first breath following a change in resistive load prior to any change in chemical drive. This suggests that immediate load compensation is not chemically mediated. Instead, it can depend on reflex neural mechanisms and the intrinsic properties of respiratory muscles.

The role of afferent feedback from the lung and lower airways, which is one of the sensory systems that may be involved in load compensation, remains controversial. Although it has been argued that vagal reflexes are minimally involved in the respiratory com- pensation for resistive loads, because of the relatively high volume threshold of the inflation reflex in awake humans [10], it should be recalled that our subjects were exercising with $\mathrm{V}_{\mathrm{T}}$ in the region of $2 \mathrm{~L}$ (Table 2), i.e., more then twice the resting level. Sensory afferents from lung and airway could potentially contribute to resistive load compensation. There are studies, suggesting that stimulation of vagal bronchopulmonary afferents are involved in regulating the ventilatory responses to bronchoconstriction [11], as well as to external and internal $\left(\mathrm{SF}_{6}-\mathrm{O}_{2}\right.$ breathing) resistive loading $[12,13]$. We showed that substitution of air by $\mathrm{He}-\mathrm{O}_{2}$ or $\mathrm{SF}_{6}-\mathrm{O}_{2}$ during exercise was accompanied by immediate changes in the volume-time values of the respiratory cycle, which is possibly related with the pulmonary stretch receptors activity. High-density gas mixture reduced the flow rate and, therefore, stimulation of receptors sensitive to dynamic component of lung tension was weaker. This decreased inhibitory afferentation from pulmonary stretch receptors could render higher EMG activity and power of inspiratory muscle contractions. We suggest that an increase in flow rate during $\mathrm{He}-\mathrm{O}_{2}$ breathing might have influenced mechanoreceptors within the respiratory tree as well. Intrathoracic irritant receptors can evoke reflex tachypnea when subjected to mechanical distortions, such as rapid lung inflation or deflation [14]. However, it has been shown that both loaded and unloaded breathing patterns were similar in normal subjects and double-lung transplant recipients in whom pulmonary afferents were absent [15]. This suggests that lung vagal afferents are not essential to the regulation of resting breathing pattern and the load compensation response in humans. Similarly, Forster et al [16, 17] have reported that decrease in neural drive to the diaphragm during resistive unloading in exercising ponies is not critically dependent on diaphragmatic and pulmonary afferents.

The human upper respiratory tract has a rich sensory supply, but information from airway receptors has been accorded a minimal role in the normal control of breathing. It has been shown that oropharynx does not make an important contribution to ventilatory responses during external mechanical loading in conscious humans. Compensatory responses to conventional mechanical loads are preserved in the absence of afferent information from the upper airways [18]. However, some authors suggest that the upper airway receptors play a significant role in the formation of adaptive reactions to changed resistive load [19].

Furthermore, proprioceptive influences (possibly from tendon organs or secondary muscle spindle endings) originating in the caudal external and internal intercostals muscles can augment phrenic efferent activity by way of a somatic reflex [20]. So, afferent information from intercostal muscle proprioceptors provides both the additional activation of the related spinal alpha-motoneurones [21] and the immediate information transmission to the bulbar respiratory structures, with the resultant changes in central inspiratory activity $[22,23]$. It is evident that not only intercostal muscle proprioceptors, but also diaphragmatic receptors participate in compensatory responses to altered resistive load. It has been suggested that the 
phrenic afferents can perceive the additional load and change motor drive. Mono- and oligosynaptic projections of phrenic afferents have been found in the cervical segments of the spinal cord and supraspinal structures, including dorsal and ventral respiratory nuclei and sensorimotor cortex [24, 25]. These facts do not exclude participation of the diaphragmatic mechanoreceptors in compensatory responses to altered resistive load, but this requires further investigations. It should be noted that the intrinsic properties of inspiratory muscles, by themselves, may also be essential for the respiratory load or unload compensation, because the force of muscle contraction depends on the velocity of its shortening and the initial muscle length [26].

In conclusion, inspiratory drive during short-time moderate exercise is controlled to compensate for changes in the internal resistive load $\left(\mathrm{SF}_{6}-\mathrm{O}_{2}\right)$ or unload $\left(\mathrm{He}-\mathrm{O}_{2}\right)$, so that minute ventilation and $\mathrm{P}_{\mathrm{ET}} \mathrm{CO}_{2}$ are preserved at a level appropriate to the metabolic rate. The mechanisms of load and unload compensation seem to be mediated by afferent information from lung and respiratory muscle receptors as well as by segmentary reflexes and intrinsic properties of the muscle fibers.

Conflicts of interest: No conflicts of interests were declared by the authors in relation to this article.

\section{REFERENCES}

1. Palange P. Lighter than air: heliox breathing improves exercise tolerance in COPD. Eur Respir Rev 2010; 115: 1-3.

2. Hunt T, Williams MT, Frith P, Schembri D. Heliox, dyspnoea and exercise in COPD. Eur Respir Rev 2010; 115: $30-8$.

3. Ward SA, Whipp BJ, Poon CS. Density-dependent airflow and ventilatory control during exercise. Respir Physiol 1982; 49: 267-77.

4. DeWeese EL, Sullivan TY, Pao LY. Ventilatory and occlusion pressure responses to helium breathing. J Appl Physiol 1983; 54: 1525-31.

5. Hesser CM, Lind F. Role of airway resistance in the control of ventilation during exercise. Acta Physiol Scand 1984; 120: 557-65.

6. Ansley L, Petersen D, Thomas A, Gibson A, Robson P, Noakes TD. The effect of breathing an ambient low density, hyperoxic gas on the perceived effort of breathing and maximal performance of exercise in well trained athletes. Br J Sports Med 2007; 41: 2-7.

7. Hussain SNA, Pardy RL, Dempsey JA. Mechanical impedance as determinant of inspiratory neural drive during exercise in humans. J Appl Physiol 1985; 59: 365-75.

8. Whitelow WA, Derenne JP, Milic-Emili J. Occlusion pressure as a measure of respiratory center output in conscious man. Respir Physiol 1975; 23: 181-99.

9. Otis AB, Fenn WO, Rahn H. The mechanics of breathing in man. J Appl Physiol 1950; 2: 592-607.

10. Widdicombe JG. Reflex control of breathing pattern. In: Respiratory Physiology I. London, 1974, Vol.2, Chapt.10, pp. 303-69.
11. Yu LK, Lee LY, Frazier DT. Effect of bronchoconstriction on breathing during normoxia and hypoxia in anesthetized cats. Respir Physiol 1984; 57: 31-45.

12. Konza EA. Breathing regulation under conditions of modified density of gaseous environment and resistive load. Physiol Zh SSSR 1979; 65: 733-42.

13. Barriere JR, Delpierre S, Del Volgo MJ, Jammers Y. Comparisons among external resistive loading, drug-induced bronchospasm, and dense gas breathing in cats: role of vagal and spinal afferents. Lung 1993; 171: 125-36.

14. Sellik H, Widdicombe JG. Vagal deflation and inflation reflexes mediated by lung irritant receptors. Qartl J Exp Physiol 1970; 55: 153-63.

15. Zhao W, Martin AD, Davenport PW. Detection of inspiratory resistive loads in double-lung transplant recipients. J Appl Physiol 2002; 93: 1779-85.

16. Forster HV, Lowry TF, Pan LG, Erickson BK, Korducki MJ, Forster MA. Diaphragm and lung afferents contribute to inspiratory load compensation in awake ponies. J Appl Physiol 1994; 76: 1330-9.

17. Forster HV, Erickson BK, Lowry TF, Pan LG, Korducki MJ, Forster AL. Effect of helium-induced ventilatory unloading on breathing and diaphragm EMG in awake ponies. J Appl Physiol 1994; 77: 452-62.

18. O’Donnell DE, Sanii R, Younes M. External mechanical loading in conscious humans: role of upper airway mechanoreceptors. J Appl Physiol 1988; 65: 541-8.

19. Winning AJ, Hamilton RD, Shea S, Knott C, Guz A. The effect of airway anaesthesia on the control of breathing and the sensation of breathlessness in man. Clin Sci 1985; 68: 215-22.

20. Shannon R. Reflexes from respiratory muscles and costovertebral joints. In: Handbook of Physiolology, Sect.3 The Respiration System. Bethesda, 1986, pp 431-88.

21. Corda M, Eklund G, Von Euler C. External and phrenic alpha-motor responses to changes in respiratory load. Acta Physiol Scand 1965; 63: 391-9.

22. Levinson RS, Mahta VJ, Badra M, Unger M. Rib cage-intercostal muscle adaptation to phrenic cutting and inspiratory airway obstructions. Am Rev Respir Dis 1977; 115: 346-54.

23. Shannon R, Shear WT, Mercak AR, Bolser DC, Lindsey BG. Non-vagal reflex effects on medullary inspiratory neurons during inspiratory loading. Respir Physiol 1985; 60: 193-204.

24. Road JD. Phrenic afferents and ventilatory control. Lung 1990; 168: 137-46.

25. Frazier DT, Revelette RW. Role of phrenic nerve afferents in the control of breathing. J Appl Physiol 1991; 70: 492-502.

26. Sharp JT. Respiratory muscles: a review of old and new concepts. Lung 1980; 157: 185-92.

Address for correspondence:

Marina Segizbaeva

6, Makarova Nab.

St. Petersburg, 199034

Russia

E-mail: marina@infran.ru 